\title{
Palaeontological Heritage: protected vs. unprotected areas. The case of Clot de Galvany Municipal Natural Park and Elche reservoir surroundings
}

\author{
Esteban José SÁNCHEZ-FERRIS
}

Museo Paleontológico de Elche (MUPE), Plaza San Juan, 03203 Elche, Alicante; appalser@yahoo.es

Sánchez-Ferris, E.J. 2019. Palaeontological Heritage: protected vs. unprotected areas. The case of Clot de Galvany Municipal Natural Park and Elche reservoir surroundings. [Patrimonio Paleontológico: áreas protegidas vs. no protegidas. El caso del Paraje Natural Municipal del Clot de Galvany y los alrededores del pantano de Elche]. Spanish Journal of Palaeontology, 34 (1), 81-84.

Manuscript received 12 February 2019

Manuscript accepted 17 May 2019 https://doi 10.7203/sjp.34.1.15252

(C) Sociedad Española de Paleontología ISSN 2255-0550

\section{ABSTRACT}

Concerning palaeontological and geological heritage of a particular place, being or not being under legal protection influences its preservation. As two examples, cases of Clot de Galvany Municipal Natural Park and Elche reservoir surroundings are exposed. Developed by the Palaeontologic Museum of Elche, Project FOPALI assessment methodology has been applied.

Keywords: Clot de Galvany, Elche reservoir, palaeontological heritage, heritage assessment.

\section{RESUMEN}

El hecho de que un paraje posea o no protección jurídica influye en la conservación de su patrimonio geológico y paleontológico. Como ejemplo, se exponen los casos del Paraje Natural Municipal del Clot de Galvany y del entorno del Pantano de Elche aplicando el modelo de valoración del Proyecto FOPALI desarrollado desde el Museo Paleontológico de Elche.

Palabras clave: Clot de Galvany, Pantano de Elche, patrimonio paleontológico, valoración del patrimonio.

\section{INTRODUCTION}

The work described here is part of the actions of FOPALI Project (Fossils and Heritage of Alicante), developed by the Palaeontologic Museum of Elche (MUPE). The main aim of this project is the integral management of the geological and palaeontological heritage, including detailed inventory of places of interest, estimates of their heritage assessments, and management measures which ensure their preservation, study, scientific disclosure and maximum use of their social and educational potential (Sánchez-Ferris, 2015).
Two of the more visited areas in the municipality of Elche are the reservoir surroundings and Clot de Galvany Municipal Natural Park (hereinafter referred to as Clot de Galvany) (Fig. 1). Their environmental relevancies have been highlighted by many authors (e.g. Gonzálvez et al., 1984; Sagasta-Sansano et al., 2007; Aranda-López \& Lacarte-Monreal, 2013).

In 2004, Elche reservoir was declared of Cultural Interest (BIC) because of its historical water infrastructure, and its surroundings are included in the List of Wetlands of the Valencian Community. In addition, in 2007 the Elche City Council drafted a project for the recovery 


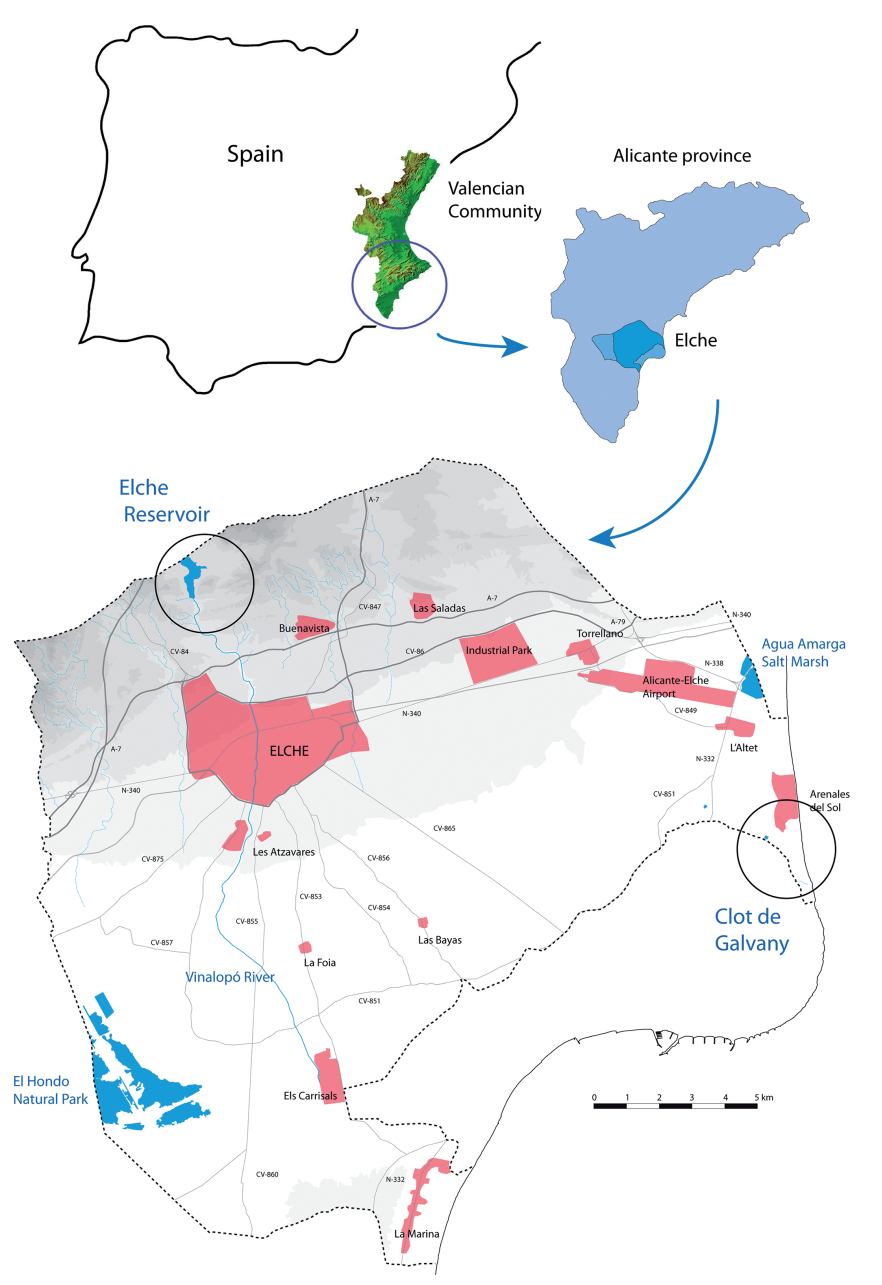

Figure 1. Map location of the studied areas (inside circles).

and valorization of the area, with a view to its future declaration as Municipal Natural Park.

Meanwhile, Clot de Galvany benefits from a greater legal coverage: since 2002 it is Biological Station and Special Protection Area for Birds (ZEPA, List of Wetlands of the Valencian Community), Municipal Natural Park since 2005, and Isla de Tabarca Community Interest Area (LIC, Natura 2000 Network) since 2006. From the management point of view, many refurbishment actions have been developed in the natural area, a renewed Park's Visitor Centre is the head office of the Clot de Galvany Control Service and Environmental Education Service (SCEA), and a non-recurrent newsletter is published since 1999.

As it happens with many natural areas regardless of its legal framework, geology and palaeontology together represent a major part of its intrinsic value. Geological history has shaped current landscapes. Palaeontology reveals present-day ecosystems time dimension. Despite this, biotic criteria generally take precedence in the protection and management of natural spaces.

On this basis, we considered to use the heritage assessment methodology developed by FOPALI Project to evaluate the geological and palaeontological interest of these two Elche areas (Fig. 2), increase their knowledge by including the fossil record and the geological history, and ascertain if differences in protective legal framework were reflected in some way in the preservation of their relevant heritage elements.

\section{METHODOLOGY}

Sixteen localities were thoroughly prospected (10 in Clot de Galvany and 6 in Elche reservoir surroundings). Previously, an exhaustive literature review had provided an updated dataset. So, site features were described and protective perimeters were GPS defined. FOPALI heritage assessment methodology was applied to all the localities. A set of three groups of escalated criteria was applied: scientific criteria, potential use criteria and deterioration risk criteria. As a result, each site can be defined by three values, which allow for the comparison between localities. So, it is possible to plan heritage management for a given area and prioritize those localities whose conservation may be more threatened.

In Sánchez-Ferris et al. (2019) a detailed methodological description of criteria, scales and analysis techniques applied is exposed.

\section{RESULTS}

The combined scientific value for the two studied areas $(40.32 \%)$ has a close relationship with the geological history of the northern margin of the Bajo Segura Basin. Worthy of note is the existence of long sections with continuous sedimentary record, great palaeoenvironmental variety, and the influence of the Crevillente Fault tectonic activity on the landscape (i.e. Martin-Rojas et al., 2015). Geological age range spans from Triassic to Quaternary. Regarding to palaeontological record, some strata have yielded a great amount of significant fossils, resulting in very high values of palaeodiversity and palaeodisparity. There exists also a type locality for a new genus and species of brachiopod and a stratotype (Complejo del Pantano Unit). From the conservation point of view, some of the sites have practically disappeared by human activity while others remain well preserved.

The combined potential use is rather high (69.17\%), mainly due to didactic interest, accessibility, proximity to densely populated cities and presence of other types of heritage (biological, archaeological, historical).

Finally, the average deterioration risk value for the two areas $(47.38 \%)$ is related to accessibility and proximity to 

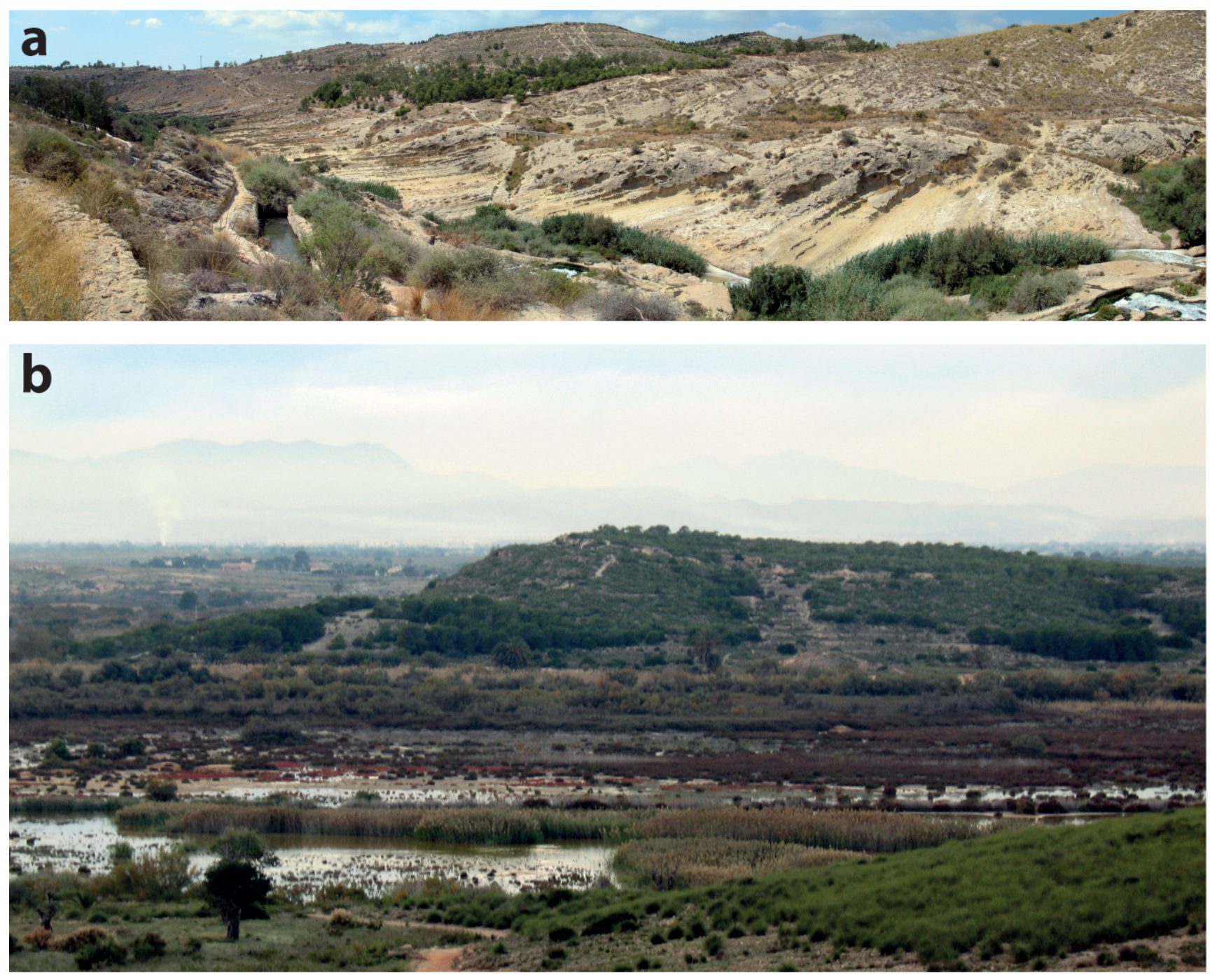

Figure 2. Views from the studies areas. a) Panoramic view of the Margas de Torremendo Formation in Elche reservoir surroundings. b) Clot de Galvany Municipal Natural Park Wetland.

big cities. Most concerning are urban growth very close to Clot de Galvany and systematic plundering in Elche reservoir surroundings.

To sum up, most of the studied localities have a potential use value above $60 \%$, and 6 out of 16 sites have a high combined scientific/potential use value.

When considering independently the values of the three groups of criteria for each of the two studied areas, some discrepancies can be found (Fig. 3). First of all, there is a remarkable $20 \%$ points of difference in scientific value between Clot de Galvany and Elche reservoir surroundings in favor of the latter. With regard to potential use value, there is much less difference. Clot de Galvany has higher values due primarily to the historical value of its localities, its high didactic interest and accessibility. Lastly, both areas have similar deterioration risk values, being Clot de Galvany less affected.

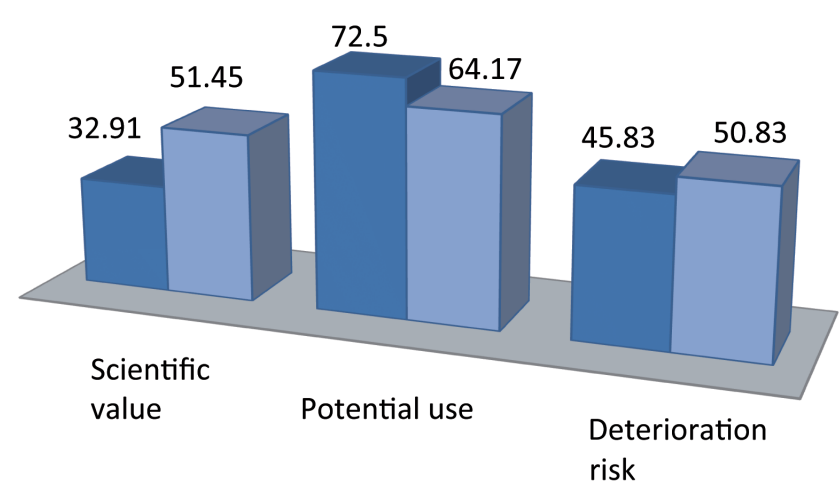

$\square$ Clot de Galvany $\square$ Elche reservoir surroundings

Figure 3. Percentage average values for the three groups of assessment criteria in each studied area. 


\section{CONCLUSIONS}

The results obtained from FOPALI heritage assessment methodology show some differences between two areas with different protective legal framework concerning heritage conservation.

Although scientific value of a certain locality does not depend on the existence of legal regulation, there can be no doubt that in protected areas there are greater possibilities of increase the knowledge (and perhaps the value) of their heritage elements.

Focusing on potential use and deterioration risk, law regulations along with proper management, undoubtedly increase the social and educational use of the public heritage, hence decreasing the risk of damage or even demise.

In the present case, it would be advisable that both areas were equally protected as Municipal Natural Park. Such a measure would greatly help with the conservation of relevant heritage elements.

\section{ACKNOWLEDGEMENTS}

The author is very grateful to the referees and editors for their useful review comments that have improved the final version of the manuscript.

\section{REFERENCES}

Aranda-López, J.C. \& Lacarte-Monreal, M.E. 2013. Plan de Especial Protección del Paraje Natural Municipal Clot de Galvany. Servicio Técnico de Planeamiento y Ordenación, Ayuntamiento de Elche, 25 pp.

Gonzálvez, V., Box, M., Cuenca, A. \& Sanjaume, E. 1984. Estudio Morfológico y Sedimentológico de la Zona del Clot de Galvany. Instituto Universitario de Geografía, Universidad de Alicante, $56 \mathrm{pp}$.

Martin-Rojas, I., Alfaro, P. \& Estévez, A. 2015. 3D geometry of growth strata in a fault-propagation fold: insights into space-time evolution of the Crevillente Fault (AbanillaAlicante sector), Betic Cordillera, Spain. International Journal of Earth Sciences (GR Geologische Rundschau), 104, 1387-1404.

Sagasta-Sansano, J., Aranda-López, J.C. \& Alemañ-García, G. 2007. Proyecto de Recuperación del Entorno del Pantano de Elche y su "Séquia Major". Servicios Técnicos de Urbanismo y Medio Ambiente, Ayuntamiento de Elche, $55 \mathrm{pp}$.

Sánchez-Ferris, E.J. 2015. Patrimonio geológico y paleontológico del término municipal de Elche: El Clot de Galvany y el Pantano de Elche. Ph.D. Thesis Universitat de València, Institut Cavanilles de Biodiversitat i Biologia Evolutiva, Valencia, 517 pp. (unpublished).

Sánchez-Ferris, E.J., Fierro-Bandera, I., Aberasturi-Rodríguez, A., Navarro-Pedreño, J. \& Montoya-Belló, P. 2019. La valoración del patrimonio geológico y paleontológico como herramienta de gestión: el Modelo FOPALI. Spanish Journal of Palaeontology, (this volume). 